Vo1. 1, No, 1, 2013, 10-17

DOI: $10.11634 / 232907811301269$

\title{
Socio- Economic Analysis of Fadama Farmers in Akure South Local Government Area of Ondo State, Nigeria
}

\author{
Folayan J. A \\ Department of Agricultural Economics and Extension Services, Joseph Ayo Babalola University Ilesa Osun State, Nigeria
}

\begin{abstract}
This study examined the socio economic analysis of Fadama farmers in Akure South Local Government Area of Ondo State. The data were collected through structured questionnaire from a sample of 100 respondents drawn from ten (10) purposively selected communities from the local Government area. The data collected was analyzed by use of percentage, frequency, descriptive statistics, gross - margin and regression analysis. The findings from the study showed that. Majority $100 \%$ of the respondents had one constraint or the other with the suggestion of new technology, adequate funding and improved input supply and provision of infrastructure to cushion their problems. The gross margin per annum of fadama farmer was N254, 000 with N21, 166.6 per month showed that fadama farming was profitable in the area of study. The regression analysis result showed that increase in the values of marital status, household size, level of that education, experience and farm size imply an will increase fadama farmers productivity while an increase in age and gender will reduce the rate of Fadama farming productivity in the study area. It was recommended that education of farmers should be encouraged while soft loan, agricultural inputs and research assistance be provided by Government. The implication findings from this study were that men were more actively involved in Fadama farming than the female, enough profit was generated to sustain the family while cooperative society was a predominant source of capital in fadama farming in the study area.
\end{abstract}

Keywords: Fadama, farming, socio economics, local government

\section{Introduction}

In Nigeria, the term "Fadama" is a Hausa name for irrigable land usually low -lying plains underlined by shallow aquifers found along major river systems. Kudi et al (2008). In addition to providing a source of water for livestock during dry seasons, Fadama also support large and diverse resident or transient wildlife including herbivores, carnivores and migratory birds NAFDO (2007). According to Kudi et al. (2002), the word "fadama" (in Hausa language) means a low lying area which is susceptible to periodic (seasonal) flooding. Fadama farming therefore implies cultivation of growing of crop under irrigation or in the dry season because flood plains are inaccessible during the normal season.

According to Ike (2012) Fadama is a tripartite funded intervention by World Bank in 1996, the Federal Government of Nigeria and participating states with objectives targeted towards poverty reduction and thus designed to improve the capacities of beneficiary group.

Fadama project is mainly aim at sustaining increase in the income of users of rural land and water resources. The need for all year round improved food production in Nigeria is inevitable with the projected annual population growth rate of 5.5 percent and food production at annual growth rate of 3.2 percent World Bank (1996).

The Agricultural sector is not only the most important non - oil economic activity in Nigeria; it is also the single largest employer of labour forces (70\% according to NBS 2007). Thus agricultural sector is often seen as important for reducing poverty. Agriculture remains the mainstay of Nigeria Economy contributing about $40 \%$ of the total cop and employing about $70 \%$ of the working population.

It is unfortunate that despite the opportunity for Nigeria to be self-sufficient in food production, there are lots of factors affecting agricultural development in the country. These include amongst others instability in government policies and the change of the economy from an agricultural driven economy of the 1960 s or early 1970 s to oil (crude oil) driven economy leading to the neglect of agricultural sector (Central Bank of Nigeria, 2000).

Apart from the economy shifting to the oil sector, it has to be noted that agricultural production in Nigeria is dictated by climatic condition. These factor determine the range of crop planted and efficiency of the crop production is rain - fed, thus determining the agricultural production system that could be exploited to support an all year round production (especially vegetables and one of such is Fadama system of farming (Ingawa, 1998). According to FAO (2000) Nigeria has a potential comparative advantage in the production of a variety of fresh and processed high value crops especially vegetable during the dry season and livestock product (meat and milk) and fisheries product throughout the year. This is because the country is endowed with underground and surface water 
reserves, rich pasture and favourable agro - ecological condition in the country's low lying with alluvial deposit known as "Fadama" hence, the National Fadama development project (NFDP) supports private production but participating farmer are organized into Fadama users association to facilitate credit borrowing loans administration and recovery.

The first National Fadama Development (NFDP) was designed in the early 1990s to promote simple low - cost improves irrigation technology under the Word Bank Financing. Ondo/Ekiti states has a total irrigable area of 146,775ha area under Fadama cultivation of maize production between 1997 and 2000 in Ondo State, while 25.5 hectares were used for rice, 113.3 hectares for okro, 1897 hectares for pepper, 288.3 hectares for tomatoes and 317.0 hectares use for amaranthus (Okunlola, 2001).

According to Omonona (2009), food security is a major problem in most developing countries of the world (Nigeria inclusive) despite natural endowment. The potential of Fadama farming to increase the food production and thus ensure food security in Ondo state is enormous. He further submitted that Annual and biannual crops that can provide quick financial returns to farmers could be grown under Fadama farming, have many farmers in Ondo State had adopted this types of farming.

The potential of Fadama farming according to Omonona (2009) has been widely documented in Ondo state as the potential of increasing food production in Nigeria and most of the crops are cultivated within a short period of time with the consequence that many farmers in Ondo state have adopted this types of farming based on its profitability. With the adoption of farmers and its consequent profitability in Ondo state, it is important to examine the socio - economic analysis of Fadama farmers in Akure South Local Government Area of Ondo State and hence the need to carry out this study. The general objectives of the study are to examine the socio economic characteristics of Fadama in Akure South Local Government of Ondo State. The specific objectives are (i) To examine socio economic characteristics of Fadama farmers (ii) examine availability and accessibility of farm inputs to the farmers (iii) identify the constraints of respondents in Fadama production and (iv) determine profitability of Fadama farmers.

\section{Literature Review}

Fadama Agriculture according to word bank report (1996) has been described as flood plains water, similar in some respect to irrigation water naturally supplied. Flood pass over the surface of the land, water is absorbed by the soil and stored for subsequent use by plant. In some regions, agriculture encourages peasant farmers to practice irrigated agriculture along the bank of the river, during the dry season when the river is flooded.
NFDP (2003) reported the benefit of Fadama Agriculture programme to include (i) increased the asset base of the participant (ii) increased the income rates as well as changed the standard of being of Fadama farmer, (iii) increased the level of technical efficiency of the farmers (iv) increased the training and knowledge of the participant in low and irrigation farming and (v) increased the supply and availability of food production all over the year. The report finally submitted that the programme has a positive impact on the farmers and has given them a wide potential of alleviating poverty in the country.

In Nigeria, the need to increase food production to feed the ever increasing human population and to diversify the export base of the country is more recognized now than ever before. This has turned the attention of both farmers and government to the exploitation of Fadama lands, which are believed to have more agricultural potential than the associated upland soils, (Kparmwang \& Esu, 1990; Singh \& Babaji 1990). The importance of Fadama stems from its high level of moisture (ground water and residual moisture) even during dry season water table is close to the soil surface thus endearing Fadama lands to farmers and making it a site of busy agricultural activities throughout the year (Singh, 1999). FAO (1996) pointed out that in the South Western Nigeria, vegetables such as amaranthus species, sokoyokoto, pepper, tomatoes and okro are very popular and farmer involved in growing this make some profit during the dry season. The motive to grow vegetable in the Fadama land is principally to make gain at a time of dry season. Farmers get an advantage over many other who have access to farm with year supply of moisture to aid crop production.

Hugus (1997) reported that the benefits derived from growing crops on the flood plain are: (i) Extension of land under cultivation and of the cropping period. (ii) Use of the labour force available at the end of the rainy season and the beginning of the dry season, (iii) Exploitation of National fertility derived from alluvial deposits, (iv) Also crop grow on receding flood supplement the poor rain fed harvest. Sandra and Agro (1996) pointed out that the development of Fadama agriculture will not only provide income to farmers but also make significant impact on the drive towards self - sufficiency in food production. The land irrigated can be cropped extensively during the rainy season as well as during the dry season, thus making the land much more productive off season production of various food crops and vegetables which command better price than those produced during the traditional growing season.

Oluwasanmi (1992) pointed out that Fadama offers one of the possibilities of increasing agricultural production and food security will be severely compromised by variability and change in many African countries. 
Over $95 \%$ of African agriculture depends on rainfall. In some countries, yield from rain fed agriculture could fall up to $5 \%$ by 2020 . Changing rainfall patterns and higher temperature are reducing agricultural yield leading to new infestations of pest, decreasing fisher's resources that are essential for some rural livehoods and increasing the frequency and flash floods affected more than one million across at least 17 countries in West, Central and East Africa (Ekong, 1996).

Nigeria is faced with the challenges of providing adequate food supply for its teaming population. With a current population of about 140 million (NPC 2006), FAO has consistently listed Nigeria among countries that is technically unable to meet their food needs from rain - fed agriculture at low level input. Furthermore, the devastating effect of desertification and drought in the last three decades on the dry sub - humid and semi - arid agro - ecological zones of Nigeria have made Nigeria Government to embark on massive investment in small scale irrigation (Ekong 2003).

The growing demand for food coupled with seasonal variations, unpredictability and unreliability that have characterized the pattern of rainfall in the sub - humid and semi - arid agro - ecological zones of Nigeria have necessitated the supplementation of rain - fed agriculture with irrigation (Iheancho et al., 2007). Sandra et al (1996) pointed out that the development of Fadama agriculture will not only provide income to the farmers but also make a significant impact on the drive toward sufficiency in crop production. The land irrigation can be cropped extensively during raining season as well as during the dry season. Thus, making the land much more productive off - season for production of various food crops and vegetables. These farm products normally command better price than those produced during the traditional rain fed growing season. F.A.O (1996) pointed out that in the south western Nigeria crop and vegetables such as rice, maize and amarantus species, tomatoes and pepper, are very popular, and are grown in dry season to make more profit. The motive to grow crop and vegetables in the Fadama land is principally to make gain at a time of dry season.

\section{The Study Area}

The study was carried out in Akure South Local Government Area of Ondo State (Figure 1). The local government occupies a geographical area of 1,591 square kilometers with population of about 420, 594 inhabitants (NPC 2006). The study area comprises of villages like Aponmu, Aule, Oda, Shagari, Isikan, Oke - Odu, Oke Obere, Igisogba, Adofure, Ita - Oniyan and Akure metropolis.

The total annual rainfall in this area is about $1,250 \mathrm{~mm}-1,500 \mathrm{~mm}$ and has bimodal distribution between March-August and August- November. The relative humidity is high $(70 \%-98 \%)$ and maximum temperature ranges between $70^{\circ} \mathrm{C}-23^{\circ} \mathrm{C}$ which is suitable for agricultural production. The major occupation of the people in the local government area are farming and trading. The major food crops grown in the area include: maize, yam, vegetables, cowpea, among others and livestock production such as; poultry, piggery, sheep and goat rearing.

\section{Methodology}

\section{Sampling techniques}

Purposive sampling technique was used to select the Local Government area based on the intensity of the Fadama farming activities. Ten (10) communities were selected from the Local Government using random sampling method.

A survey of the ten communities indicated that there were 130 fadama farmers in the local Government Area. Primary data were collected with the use of structured questionnaires to interview one hundred and fifteen (115) fadama farmers in the study area. Only 100 questionnaires were valid for analysis. The selected farmers have consistently been in fadama farming for a minimum of five years. The data used in this study were obtained through the use of structured questionnaire. The questionnaire elicited information on socio-economic characteristics of the respondent, such as gender, marital status, educational status, Method of land acquisition, source of capital source of labour, method of land preparation varieties crop planted; source of planting materials access to implements and availability of input crops cultivated

\section{Method of data analysis}

Data collected was analyzed by using percentage, frequency, descriptive statistics, gross - margin and regression analysis.

Descriptive statistics such as frequency and percentage were used to analyze socio- economic characteristics of the Fadama farmers, while. Also gross margin was used to analyze the profitability of Fadama farming production.

Gross margin is the difference between total revenue and total variable cost. Total revenue is the product of price per unit of output.

$\mathrm{GM}=\mathrm{TR}-\mathrm{TVC}$

\section{Regression analysis}

The linear regression model is as specified bellow

$\begin{array}{lll}\mathrm{Y} & = & \mathrm{f}\left(\mathrm{X}_{1}, \mathrm{X}_{2}, \mathrm{X}_{3}, \mathrm{X}_{4}, \mathrm{X}_{5}, \mathrm{X}_{7}, \mathrm{X}_{8}\right) \\ \mathrm{Y} & = & \text { income per production } \\ \mathrm{X}_{1} & = & \text { Age of the respondents } \\ \mathrm{X}_{2} & = & \text { Gender } \\ \mathrm{X}_{3} & = & \text { Marital Status } \\ \mathrm{X}_{4} & = & \text { Household Size }\end{array}$




$\begin{array}{lll}\mathrm{X}_{5} & = & \text { Level of education } \\ \mathrm{X}_{6} & = & \text { Experience } \\ \mathrm{X}_{7} & = & \text { Farm size in hectares } \\ \mathrm{e}_{1} & = & \text { Error term }\end{array}$

\section{Result and Discussion}

The socio - economic characteristics of Fadama farmers in Akure south Local Government Area of Ondo State is presented in Table 1 with $64 \%$ of the respondents being male implying that men were found to be more active participant than their female counterpart in Fadama farming in the area of study.

Also majority $(66 \%)$ of the respondents are married with $34 \%$ of them falling into the category of either being single, divorce, widowed or separated. This may indicate that Fadama farming can generate enough income to sustain the family.
Also the educational status of the respondent shows that about $57 \%$ of the Fadama farmers had secondary education, $20 \%$ had tertiary education while $12 \%$ and $7 \%$ had primary and adult education respectively while $4.0 \%$ of the fadama farmers had no formal education. The implication is that adoption of new technology by the fadama farmer may be higher in the study area. Also indicated in the Table is that $50 \%$ of the respondents cultivated vegetables, $43 \%$ grown grains while $3 \%$ cultivated tuber crops. This simply reflects perceived conception of fadama farming being associated with vegetable cultivation.

The Table also revealed that $63 \%$ of the respondent acquired the land being used via inheritance and purchase. The implication is that the fadama farmers in the study area had high level of ownership right in the land being used.

Table 1. Socio Economic Characteristics of Fadama farmers.

\begin{tabular}{lll}
\hline Gender & Frequency & Percentage (\%) \\
\hline Male & 64 & 64.0 \\
Female & 36 & 36.0 \\
Total & 100 & 100.0 \\
Marital Status & Frequency & Percentage (\%) \\
Married & 66 & 66.0 \\
Single & 13 & 13.0 \\
Divorce & 11 & 11.0 \\
Induced & 7 & 7.0 \\
Separated & 3 & 3.0 \\
Total & 100 & 100.0 \\
Educational & Frequency & Percentage $(\%)$ \\
Primary education & 12 & 12.0 \\
Secondary education & 57 & 57.0 \\
Tertiary education & 20 & 20.0 \\
Adult education & 7 & 7.0 \\
Crops cultivated & Frequency & Percentage $(\%)$ \\
Grains & 43 & 43.0 \\
Vegetable & 54 & 54.0 \\
Tuber & 3 & 3.0 \\
Total & 100 & 100.0 \\
\hline
\end{tabular}

The Table 2 shows that $44 \%$ of respondents sourced for capital through cooperative society. Thus implying that the cooperative society is the most predominant source of capital for the respondents.

Table 2 shows that $80 \%$ of the respondents used hired labour to operate Fadama and thus implying that the operation of the Fadama farmers in the area of study is largely commercially oriented. The Table revealed that $83 \%$ of the respondents used mechanical means of land preparation. This may imply that land preparation via mechanical means ensures higher output in Fadama operation.

According to the result $86 \%$ of the respondents planted improved seeds and this imply that respondents in the study area have access to use of improved varieties of seeds. Also the table showed that $78 \%$ of the respondents got their planting materials from Government. This implies that the major source of planting materials for Fadama farming in the study area is through the government. Also the table further showed that $91 \%$ of the respondents made use of hired implements. The implication is that they do not have enough capital to purchase farm implements. Also $95 \%$ of the respondents made use of available input of fertilizer and $57 \%$ of the respondents made use of available input of pesticides. The implication of this is that majority of the respondents have access to fertilizer and pesticide inputs. 
Table 2. Socio economic characteristics of Fadama farmers.

\begin{tabular}{|c|c|c|}
\hline Method of land acquisition & Frequency & Percentage $(\%)$ \\
\hline Lease & 37 & 37.0 \\
\hline Inheritance & 41 & 41.0 \\
\hline Purchase & 12 & 12.0 \\
\hline Gift & 10 & 10.0 \\
\hline Total & 100 & 100.0 \\
\hline Source of Capital & Frequency & Percentage $(\%)$ \\
\hline Personal savings & 32 & 32.0 \\
\hline Commercial bank & 10 & 10.0 \\
\hline Cooperative Society & 44 & 44.0 \\
\hline Relations and friend & 14 & 14.0 \\
\hline Total & 100 & 100.0 \\
\hline Source of labour & Frequency & Percentage $(\%)$ \\
\hline Hired & 80 & 80.0 \\
\hline Family & 20 & 20.0 \\
\hline Total & 100 & 100.0 \\
\hline Method of land acquisition & Frequency & Percentage $(\%)$ \\
\hline Manual & 15 & 15.0 \\
\hline Mechanical & 83 & 83.0 \\
\hline Animal power & 2 & 2.0 \\
\hline Total & 100 & 100.0 \\
\hline Crops varieties planted & Frequency & Percentage $(\%)$ \\
\hline Imported seed & 86 & 86 \\
\hline Local seed & 14 & 14 \\
\hline Total & 100 & 100 \\
\hline Source of planting material & Frequency & Percentage $(\%)$ \\
\hline Previous harvest & 15 & 15.0 \\
\hline ADP & 27 & 27.0 \\
\hline Ministry o Agric. & 57 & 57.0 \\
\hline Market & 7 & 7.0 \\
\hline Total & 100 & 100.0 \\
\hline Access to implement & Frequency & Percentage $(\%)$ \\
\hline Hired & 91 & 91.0 \\
\hline Free & 11 & 11.0 \\
\hline Total & 100 & 100.0 \\
\hline Availability of input (fertilizer) & Frequency & Percentage $(\%)$ \\
\hline Available & 95 & 95.0 \\
\hline Not available & 5 & 5.0 \\
\hline Total & 100 & 100.0 \\
\hline Pesticides & Frequency & Percentage $(\%)$ \\
\hline Available & 57 & 57.0 \\
\hline Not available & 43 & 43.0 \\
\hline Total & 100 & 100.0 \\
\hline
\end{tabular}

Table 3 reveled that all $(100 \%)$ of the respondents fadama farmers had one constraints or the other. This may imply that more are still needed to be done in order to help the fadama farmers to overcome source problems that are associated with fadama farming.

Table 3. Constraints and suggestion to the problems of Fadama farmers.

\begin{tabular}{lll}
\hline Constraints & Frequency & Percentage (\%) \\
\hline Inadequacy of equipment & 11 & 11.0 \\
Poor price of farm product & 3 & 3.0 \\
Unavailability of fertilizer & 4 & 4.0 \\
Unavailability of improved seed & 8 & 8.0 \\
Inadequacy of extension Agents & 10 & 10.0 \\
Non implementation of research & 13 & 13.0 \\
recommendation & & \\
Inadequacy capital & 10 & 10.0 \\
Inadequacy of storage facilities & 11 & 11.0 \\
High cost transportation & 13 & 13.0 \\
Problems of pest \& diseases & 11 & 11.0 \\
Unavailability of credit facilities & 3 & 3.0 \\
Inadequate of market & 3 & 3.0 \\
Total & 100 & 100.0 \\
\hline
\end{tabular}


The Table 4 revealed that 29\% suggested new technology, $31 \%$ suggested adequate funding, $21 \%$ suggested improved input supply while, $19 \%$ suggested provision of infrastructure.

Table 4. Suggestions to problems on Fadama farming.

\begin{tabular}{lll}
\hline Suggestion to problems & Frequency & Percentage (\%) \\
\hline New technology & 29 & 29.0 \\
Input supply & 21 & 21.0 \\
Adequate funding & 31 & 31.0 \\
Provision of infrastructure & 19 & 19.0 \\
Total & 100 & 100.0 \\
\hline
\end{tabular}

\section{Gross margin analysis}

The detail analysis of gross margin in respect of the fadama farmer is shown in Table 5. The result showed that the profit realized from fadama farming per participant per annum was N254, 000 given a gross margin of $\mathrm{N} 21,166.66$ per participant per month. This could imply that fadama farming is profitability

Table 5. Gross margin analysis of Fadama farming.

\begin{tabular}{|c|c|c|}
\hline \multirow{8}{*}{$\begin{array}{l}\text { Total variable cost } \\
\text { per production }\end{array}$} & Fertilizer & $\mathrm{N} 3660,000$ \\
\hline & Chemical & N905, 000 \\
\hline & Transportation cost & N807, 000 \\
\hline & Labour & $\mathrm{N} 2120,000$ \\
\hline & Planting material & N926, 000 \\
\hline & Repair and maintenance & $\mathrm{N} 109,000$ \\
\hline & Miscellaneous & N875,000 \\
\hline & Total variable cost & $\mathrm{N} 9402,000$ \\
\hline \multirow{7}{*}{$\begin{array}{l}\text { Total revenue per } \\
\text { production }\end{array}$} & Income from maize & $\mathrm{N} 22,000,000.00$ \\
\hline & Income from yam & $\mathrm{N} 2,790,000.00$ \\
\hline & Income from tomatoes & $\mathrm{N} 1,260,000.00$ \\
\hline & Income from okro & $\mathrm{N} 652,000.00$ \\
\hline & Income from leafy vegetable & N6,240,000.00 \\
\hline & Income from pepper & $\mathrm{N}, 870,000.00$ \\
\hline & Total income GR & $\mathrm{N} 34,812,000.00$ \\
\hline
\end{tabular}

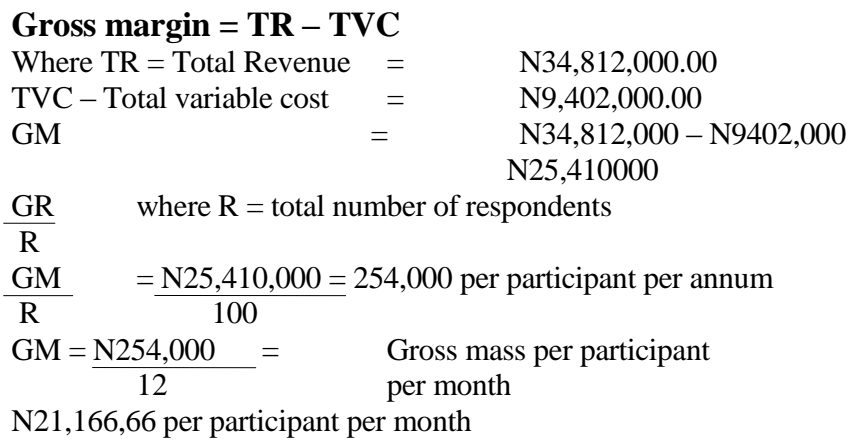

\section{Regression analysis on Fadama farming}

Table 5 showed the coefficient of multiple determination $\mathrm{R}^{2}$ is 0.413 . This implies that $41.31 \%$ of the variability in income generated from fadama farming are accounted for by the specified independents variable. The positive sign associated with marital status (X3), household size (X4), level of education (X5), experience (X6), and farm size (X7) imply that an increase in the value of these variables will increase in Fadama farmers productivity.

On the other hand the negative sign associated with Age (X1), and gender (X2) implied that an increase in their value will reduce and affect the rate of Fadama farmers productivity. 
Table 5. The result of regression analysis.

\begin{tabular}{lll}
\hline Variables & Estimated coefficients & Standard Error \\
\hline Constant & 140393.147 & 96742.769 \\
Age of respondents $\left(\mathrm{X}_{1}\right)$ & 71,3700 & 2106.430 \\
Gender $\left(\mathrm{X}_{2}\right)$ & $83,368.277$ & 37322.514 \\
Marital status $\left(\mathrm{X}_{3}\right)$ & $2,189.832$ & 15559.740 \\
Household size $\left(\mathrm{X}_{4}\right)$ & $1,360 . .561$ & 9758.909 \\
Level of Education $\left(\mathrm{X}_{5}\right)$ & $10,422.583$ & 15559.909 \\
Experience $\left(\mathrm{X}_{6}\right)$ & $1,354.172$ & 1868.448 \\
Farm size in length $\left(\mathrm{X}_{7}\right)$ & $5,564.974$ & 10911.883 \\
$\mathrm{R} 2$ spared & 0.413 & \\
R2 Adjusted required & 0.369 & \\
F2 statistics & 9.264 & \\
5\% level of significance & & \\
\hline
\end{tabular}

\section{Recommendations}

Premised on the findings from the study, the following recommendations were made.

-Government should provide soft loan to Fadama farmers in other to increase their production.

-Government should encourage research to improve research work on Fadama farming.

-Government should further assist Fadama via input subsidy.

\section{Conclusion}

The research result showed that majority (66\%) of the respondents were married, $96 \%$ of the respondents had one form of formal education or the other, $89 \%$ of the respondents had access to hired implement, $78 \%$ planted improved seed collected from the government, $80 \%$ of the respondents used hired labour. Also all the faced one problem or the other. The problem ranged from inadequacy, of new technology, inadequate input supply. If the government can come to the aid of Fadama farmers by providing soft loan, introduce new technology and improve on extension services to boost Fadama farming productivity in other to make food available year round in the area of study.

The implication of findings from the study were men were more actively involved in fadama farming to sustain the family while cooperative society was a predominant source of capital in fadama farming in the study area. The gross margin per annum of Fadama farmer is N254, 000 and per respondents per month was N21, 166.6 which revealed that Fadama farming was profitable in Akure South Local Government Area of Ondo State. The result of regression analysis revealed that marital status, household size, level of education, experience and farm size imply an increase in the value of those variables will increase in Fadama farmers productivity while an increase in Age and gender, will reduce the rate of Fadama farming productivity in the study area.

\section{References}

Aladetoyinbo, R.O (2001). Designing an operational analysis and field layout procedure for Fadama development in Ondo State $18^{\text {th }}$ December, 2001, 2-3

Central Bank of Nigeria (2000). The Changing structure of the Nigeria economy and implication for development: Realm Communications Lagos, $31-40$

Ekog, (1996). Effect of climate and weather on food crops in Nigeria. Macmillan Press Limited ,330: 3 -7

Fasasi, (2003): Keynote address of the programme manager of Ogun State agriculture development project (OGADEP) at the $1^{\text {st }}$ August Farmers Seminar and Training workshop Organized by Farmer Society of Nigeria (Ogun State chapter) At OGADEP Abeokuta of July $31^{\text {st }} 2003,4$.

FAO, (2000). Irrigation extension for effective Fadama in Nigeria: FAO Publication division great Britain, 31.

FAO, World Bank, (2000). Fadama farming improvement and the Nigeria Economy Farmer Department Country Profiles, Nigeria REV 4 March 2000, 10 - 13.

Hughes (1997). Irrigation principle and practice, John Willery and Sons, Inc. UK, Third Edition. Pp7

Ike P. C. (2012). An analysis of the impact of Fadama III project on poverty alleviation in Delta State, Nigeria, Asian Journal of Agricultural Sciences 4(2), 158 - 164

Ingawa S. A. (1998). National Fadama Development Project (NFDP). Achievement constraint and prospects. In irrigation for sustainable agriculture (IAR) Samaturu, Zaria, 188- 201

Iheanacho A. C, Abaja A. \& Harina L (2007). Beneficiating assessment of the second National Fadama Development: A draft report submitted to Adamawa SFDO, 2007

Jones,S.M.C \& Olayemi, A (1990). Certificate agriculture science. Longman Group Limited Nigeria, 23 - 24.

Kparmweng, T. \& Esu I.E (1990). Characteristics and agricultural land use of Fadama soils in the savanna Region of Nigeria: Review, 11: $116-131$.

Kudi A.M, Ani S.O \& Oredipe A.A (2008). Poverty reduction and increased productivity through empowerment" CPU NFDO Fadama Development Project October 2008 Pp 4

NFDP II (2003). Fadama II poverty reduction through empowerment, A publication of PCU - NFDO Abuja, Nigeria

NAFDO (2007). National Fadama Development office Poverty Reduction through increased productivity and empowerment; Abuja Nigeria.

National Population Commission (2006). Estimated population figures. National Population commission of Nigeria, Abuja.

NBC (2007). National (Bureau of Statistics, Nigeria Poverty Assessment (harmonized). National Bureau of Statistics, Abuja.

Olubusin, (1994). A review of integrated Fadama farming highlight of the Nigeria. Scenario National Institutes for Fresh Water Fisheries Research. New Busa, 2- 3.

Olusanmi, H.A (1996). Impact of higher agriculture education of food and agriculture, Special Publication Vol. 81996. 
Okunola, J.O (2001). The role of Extension officers in facilitating Fadama development in Ondo State. A paper presented at seminar on supervisory Management of available resources for Fadama development project. Ondo State ADP December, 2001, 2-6.

Omonina, B.T (2009). Quantitative analysis of rural poverty in Nigeria, Nigeria strategy Support Programme (N.SSP) Background paper 9, International Food Policy Research Institute Washington D.C

Sandra, A.O \& S. B Ago (1996). Longman, UK First Edition, 1.
Yangbu \& Stringhan, (1990). Irrigation Principle and practices, John Willery and Sons Inc Uk, third Edition.

Sign, B. R (1990). Fertility and salinity/ solidity status of Fadama soils in north- western Nigeria. 1 Kebbi State, Nigeria Journal of Basic and Applied Sciences 8, 1 -14.

Singh, B.R \& Babaji G. A (1990). Characteristics of the soil in Dundaye District. 2. The Fadama Soils of University Farm Nigeria Journal of Basic and Applied sciences 4, 29-30.

World Bank, (1996). Project Appraisal Document (PAD) for the second National Fadama Development project Unpublished Document. 